\title{
Analisis dan Perancangan Sistem Informasi e-Commerce Berbasis Web Pada UMKM Batik Rindani Jambi
}

\author{
Dedy Setiawan dan Lutfi \\ Program Studi Akuntansi Fakultas Ekonomi dan Bisnis Universitas Jambi \\ J1. Jambi-Ma. Bulian KM 15 Mendalo Darat Jambi 36361 \\ email: dedy_doel@yahoo.com; serverlutfi@gmail.com
}

\begin{abstract}
ABSTRAK
Tujuan dari penelitian ini adalah untuk merancang sistem aplikasi E-Commerce berbasis Web pada UMKM Batik Rindiani. Yang nantinya akan dapat membantu kegiatan penjualan dan promosi produk. Salah satunya adalah fasilitas penting yang bisa dimanfaatkan oleh pelanggan yaitu berupa fitur-fitur forum diskusi, List data Produk, penginputan data, informasi produk yang tersedia. Dalam pengembangan sistem ini peneliti menggunakan bahasa pemrograman $P H P$, dimana bahasa pemograman ini digunakan untuk membangun aplikasi Web, Sedangkan basis data yang digunakan adalah MySQL. Metodologi pengembangan sistem yang peneliti gunakan adalah metodologi Waterfall. Metodologi Waterfall ini memiliki beberapa tahapan yaitu Analisis, Perancangan Sistem, Implementasi, Integrasi, Operasi dan Pemeliharaan. Dalam proses pengumpulan data peneliti menggunakan metode observasi, wawancara dan studi pustaka. Adapun keluaran yang akan dihasilkan dari pengembangan sistem ini adalah aplikasi E-Commerce berbasis Web.
\end{abstract}

\section{Kata Kunci: Aplikasi E-Commerce, Pemrograman dan Aplikasi}

\section{PENDAHULUAN}

Perkembangan teknologi Internet dewasa ini memungkinkan setiap orang untuk memperoleh informasi secara cepat dan akurat, peranan informasi yang cepat dan akurat tersebut menghasilkan keputusan dan perkembangan yang cepat pula.Teknologi komputer memiliki kemampuan untuk mendukung pembentukan system informasi manajemen yang mampu menyerap data. Mengolah dengan prosedur tertentu. Menyajikan dalam bentuk informasi juga mendistribusikannya kepada pihak yang berkepentingan.(Rinaldi, 2012).

Saat ini perusahaan berlomba-lomba untuk menjadi pemimpin pasar dengan meningkatkan pelayanan dan kualitas produknya. Perusahaan juga dituntut untuk menerapkan strategi dan langkah yang tepat agar tidak tertinggal oleh trend dan perkembangan yang ada. Salah satu faktor penting yang menjadikan suatu perusahaan unggul adalah kemampuan untuk menjawab kebutuhan pasar.

Untuk memenuhi kebutuhan pasar tersebut, teknologi informasi memegang peranan yang penting. Pemanfaatan teknologi yang tepat akan menghasilkan informasi yang terkini. Teknologi internet semakin berkembang terutama dalam dunia bisnis, hal ini dapat dilihat dengan munculnya electronic commerce (E-Commerce). Dengan membawa keunggulan internet dalam proses bisnis khususnya kegiatan promosi dan layanan pembelian produk, menjadikan E-Commerce diaplikasikan oleh banyak organisasi bisnis. Kehadiran E-Commerce dalam suatu organisasi bisnis akan memberikan manfaat bagi perusahaan yang 
mengaplikasikannya. Hal ini tentunya menjadi keunggulan kompetitif bagi perusahaan. (Rudi 2008).

Besarnya peranan E-Commerce pada perekonomian banyak Negara telah membuat E-Commerce menjadi salah satu mata kuliah yang banyak ditawarkan bagi mahasiswa baik fakultas teknik maupun fakultas bisnis. Oleh karna itu dengan jelas terlihat besarnya implikasi dan bobot dari E-Commerce bagi perekonomian global.

Dengan kemudahan dan keuntungan pengunaan sistem informasi E-Commerce, maka secara rasional akan meningkatkan layanan penyediaan informasi khususnya di bidang penjualan, dan dapat meningkatkan efektifitas pengelolanya karena mereka bisa mengerjakan pekerjaan produktif lainnya, meningkatkan profesionalisme sistem, dan sebagainya.

UMKM Batik Rindiani merupakan UMKM bergerak di bidang pembuatan Batik khas Jambi. UMKM ini beralamat di JL. Sumantri Brojonegoro Komplek Setia Negara Blok. F.8F Sipin Jambi, UMKM ini berdiri pada tahun 2002 yang mana UKM ini mampu melakukan penjualan sebanyak 5 Item batik perbulannya, harga perbatiknya kisaran Rp 150.000 s/d Rp 2.500.000,-. Strategi pemasaran dan penjualan Batik Rindiani masih dilakukan secara tradisional sehingga terdapat beberapa kekurangan dan keterbatasan. Dalam persaingan bisnis yang semakin pesat, UMKM Batik Rindiani memerlukan strategi pemasaran dan penjualan baru yang menjangkau pasar lebih luas sehingga diharapkan dapat meningkatkan penjualan dan memberikan pelayanan yang lebih baik kepada pelanggannya.

\section{Permasalahan Penelitian}

Dari uraian pada bagian pendahuluan terlihat bahwa betapa pentingnya tata kelolah penjualan dan promosi produk yang baik khususnya dengan mengunakan Sistem Informasi, namun masih banyak UMKM yang belum dapat mengelolah penjualan dan promosi produk yang baik dalam pengunaan Sistim Informasi sehingga sering terjadi di beberapa UMKM adalah kesulitan dalam melakukan penjualan dan promosi produk yang menjangkau pasar yang lebih luas sehingga berdampak kurang efektifitas dan efisiensi tata kelolah penjualan dan promosi produk khususnya UMKM Batik Rindiani baik dari segi biaya, tenaga maupun waktu.

\section{Tujuan Khusus Penelitian}

Menghasilkan sebuah Blueprint Perancangan Sistem dan Rancang Bangun Sistem Informasi E-Commerce dan Implementasi Sistem Informasi E-Commerce berbasis web di UMKM Batik Rindiani Jambi yang bertujuan untuk meningkatkan efektifitas dan efisiensi tata kelolah penjualan dan promosi produk baik dari segi biaya, tenaga, maupun waktu.

\section{Manfaat Penelitian}

Sistem Informasi E-Commerce mempunyai banyak manfaat bagi semua pemegang kepentingan (stakeholder). Selain mempermudah dan merapikan proses tata kelolah penjualan dan promosi produk, Sistem Informasi E-Commerce juga meningkatkan omset penjualan dari UMKM Batik Rindiani.

Adapun manfaat dari Sistem Informasi E-Commerce berbasis web ini adalah sebagai berikut:

1. Mempermudah pendataan produk.

2. Mempermudah dan mempercepat proses pencarian produk-produk.

3. Merapikan dan memberikan standard format informasi akademik 
4. Meningkatkan efisiensi terutama karena berkurangnya dukumen yang harus dicetak secara fisik

5. Mempermudah konversi data penjualan ke format lain untuk diolah kembali maupun untuk disajikan secara langsung

6. Meningkatkan transparansi informasi penjualan.

7. Sebagai salah satu sarana promosi yang dapat meningkatkan prestise UMKM.

\section{Target Penelitian}

Target penelitian ini adalah membuat Sebuah BluePrint rancangan dan sebuah aplikasi Sistem Informasi E-Commerce berbasis Web yang mana aplikasi ini nantinya akan memiliki kelebihan-kelebihan sebagai berikut:

1. Kompatibel untuk semua Operating System

2. Berbasis Web sehingga:

a. Mudah diakses dari semua Komputer

b. Tidak memerlukan aplikasi klien tambahan

c. Tidak tergantung kepada sistem operasi tertentu

3. Tidak memerlukan perangkat dengan spesifikasi tinggi

4. Data dapat diekspor ke format lain

5. Dapat dikembangkan sesuai dengan kebutuhan

\section{METODE PENELITIAN}

Metodologi penelitian ini mengunakan Metode pengembangan sistem metode SDLC(Sistem Development Life Cycle) atau sering disebut sebagai pendekatan air terjun (waterfall). Metode waterfall pertama kali diperkenalkan oleh Windows W. Royce pada tahun 1970. Waterfall merupakan model klasik yang sederhana dengan aliran sistem yang linier Output dari setiap tahap merupakan input bagi tahap berikutnya (Kristanto, 2004).

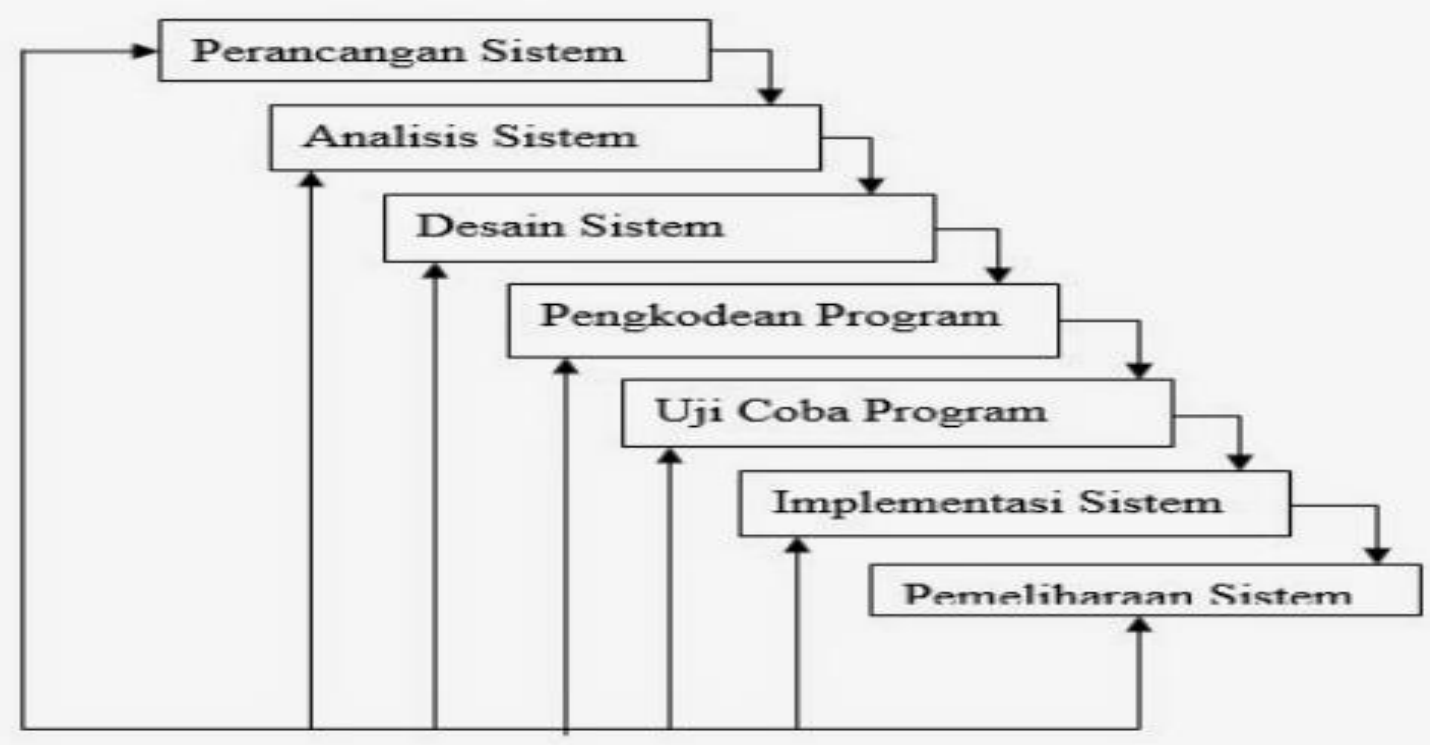

Gambar 1. Tahap Model Waterfall 


\section{Kerangka Kerja Penelitian}

Kerangka kerja yang digunakan dalam penelitian ini adalah sebagai berikut:

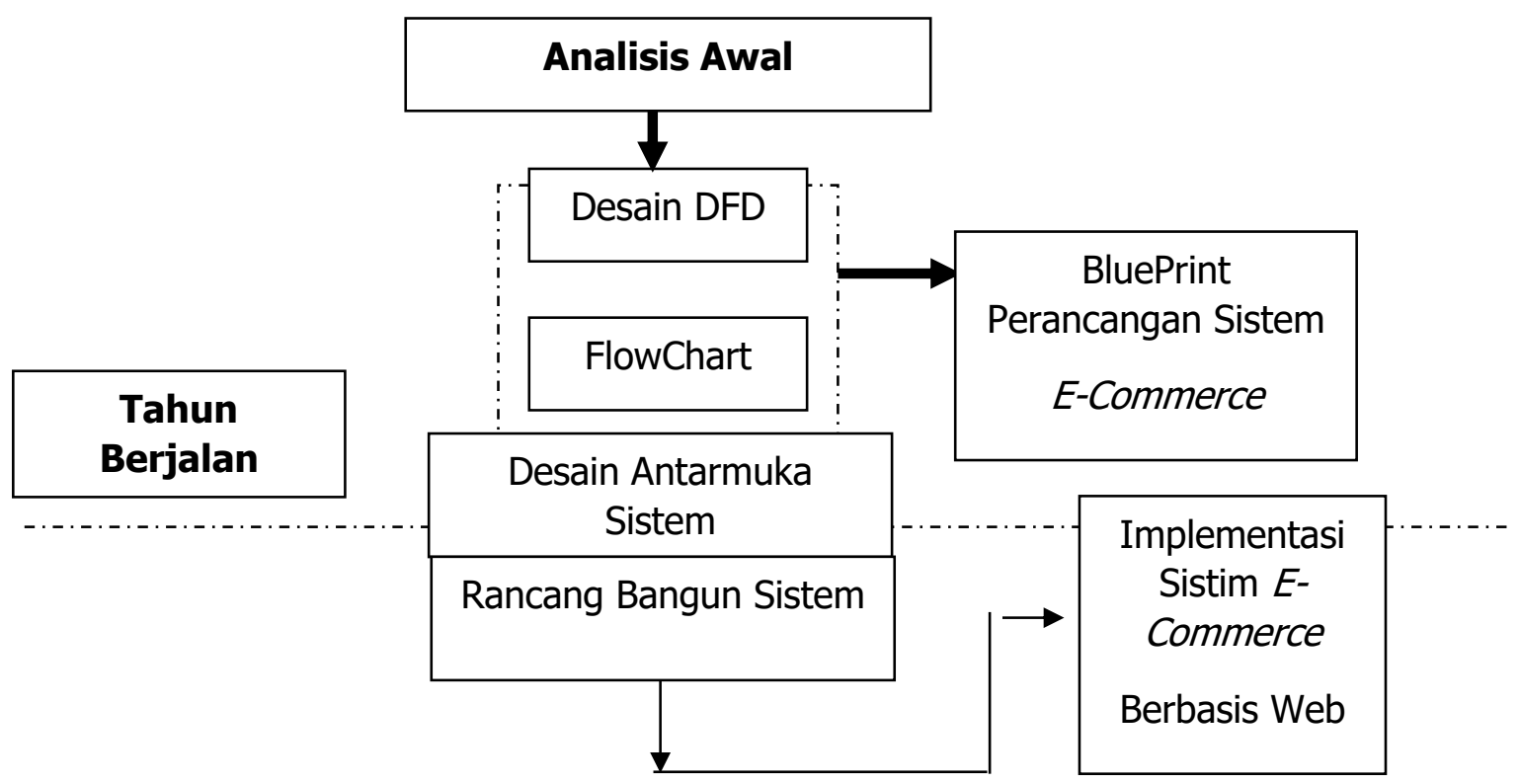

Gambar 2. kerangka Kerja Penelitian

\section{HASIL DAN PEMBAHASAN}

\section{Data Flow Diagram}

Data flow diagram merupakan alat yang digunakan pada metodologi pengembangan sistem yang sering digunakan untuk menggambarkan suatu sistem yang telah ada atau sistem baru yang dikembangkan secara logika dimana data tersebut mengalir.

\section{Diagram konteks}

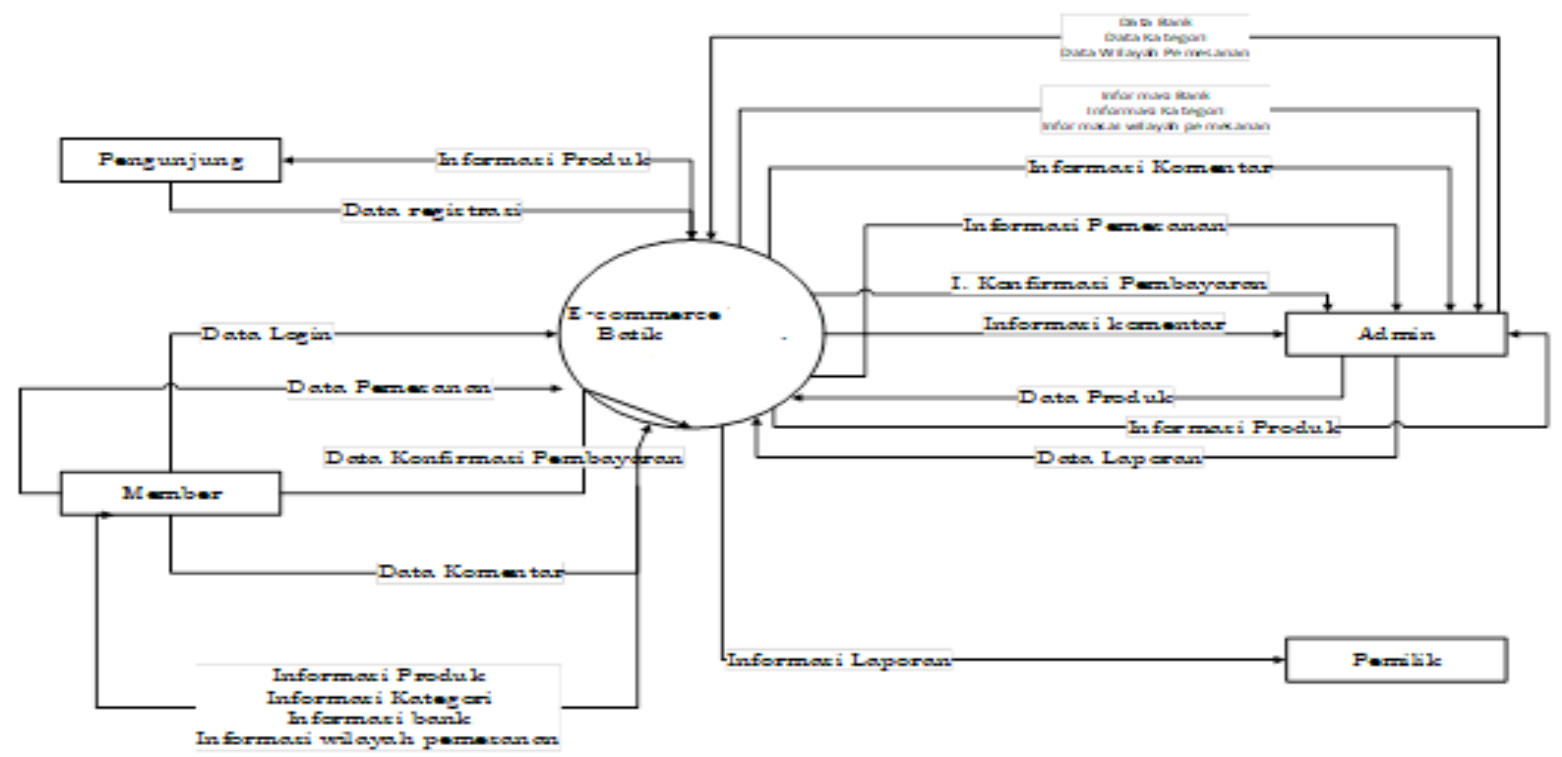

Gambar 3. Diagram Konteks 


\section{DFD Level 0}

\section{Entity Relationship Diagram}

ERD (Entity Relationship Diagram) merupakan suatu diagram yang menggambarkan rancangan data yang akan disimpan atau bentuk logika yang akan dipakai untuk menganalisa dan mendesain suatu basis data yang akan dibuat.

Adapun ERD pada sistem informasi E-Commerce ini adalah sebagai berikut :

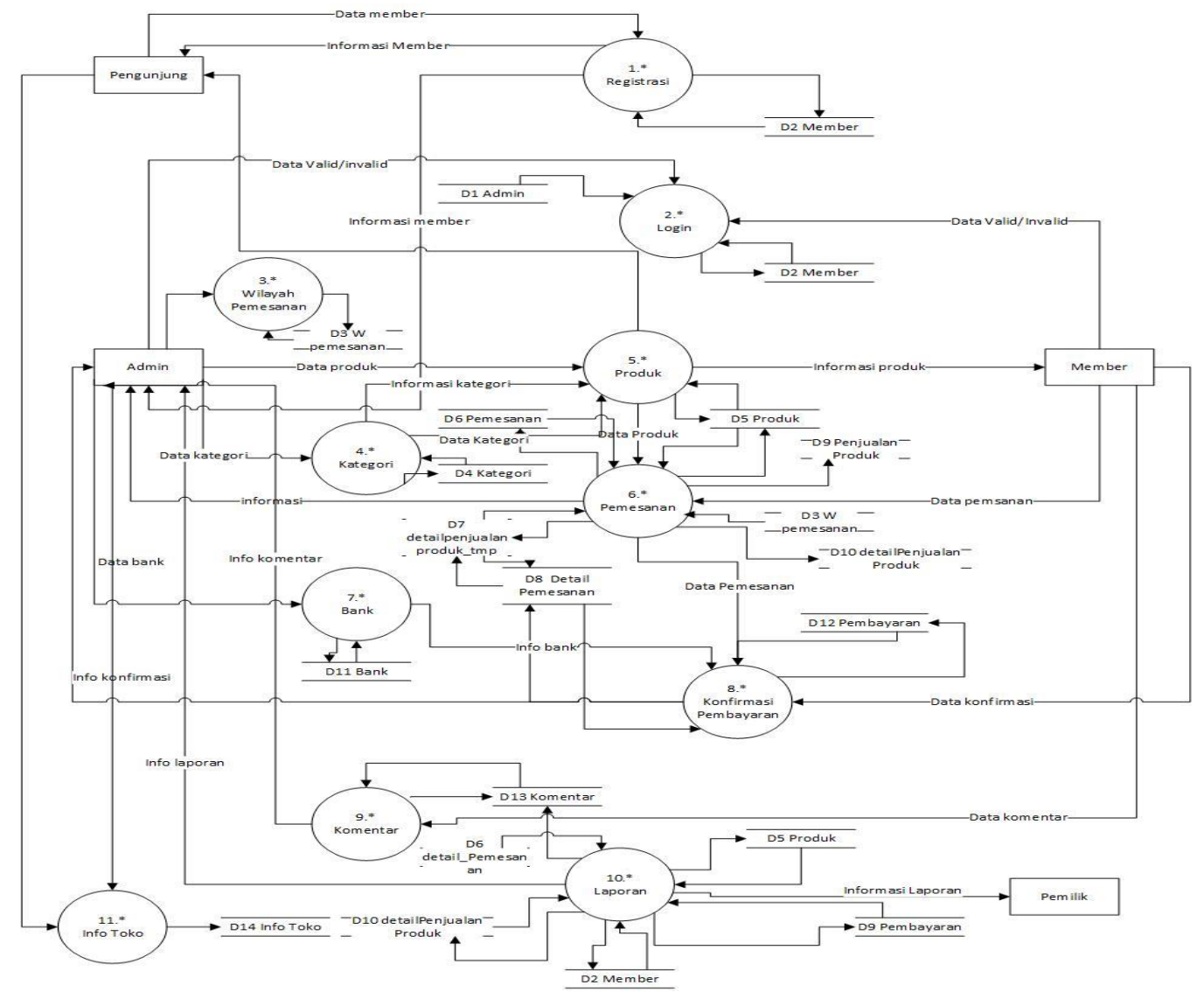

Gambar 4. DFD Level 0

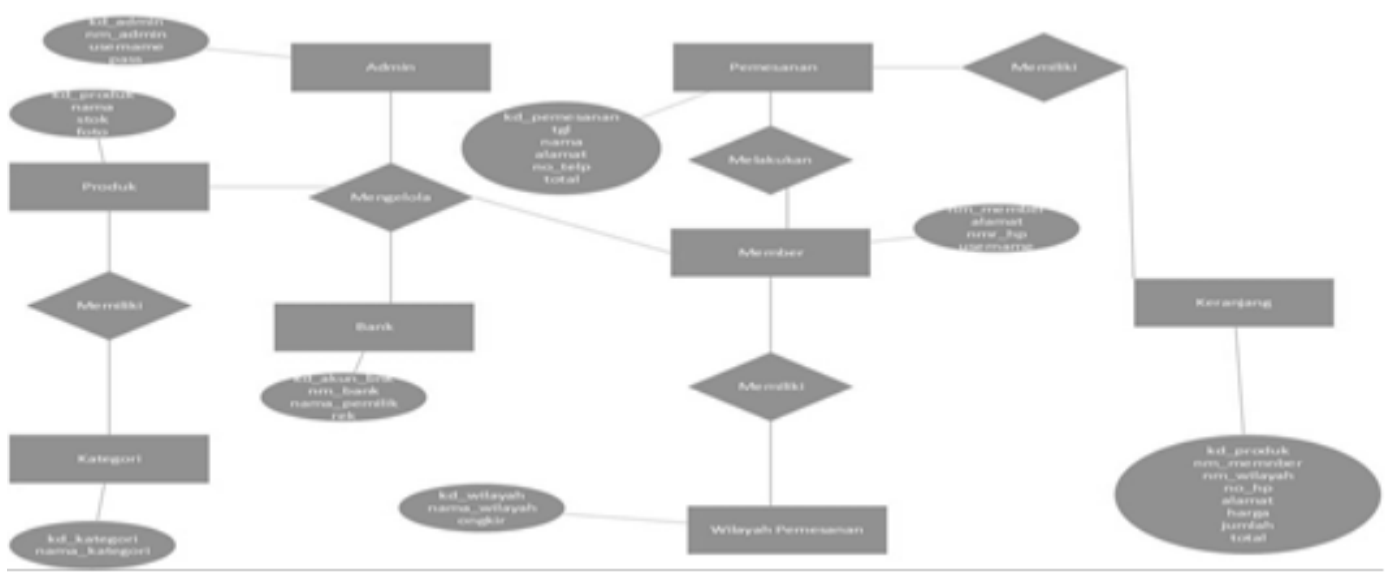

Gambar 5. Entity Relationship Diagram (ERD) 
Jurnal Sains Sosio Humaniora

Volume 2 Nomor 1 Januari - Juni 2018

\section{Logical Record Structure (LRS)}

Berikut adalah relasi database dari sistem informasi E-Commerce pada UMKM Rindiani.

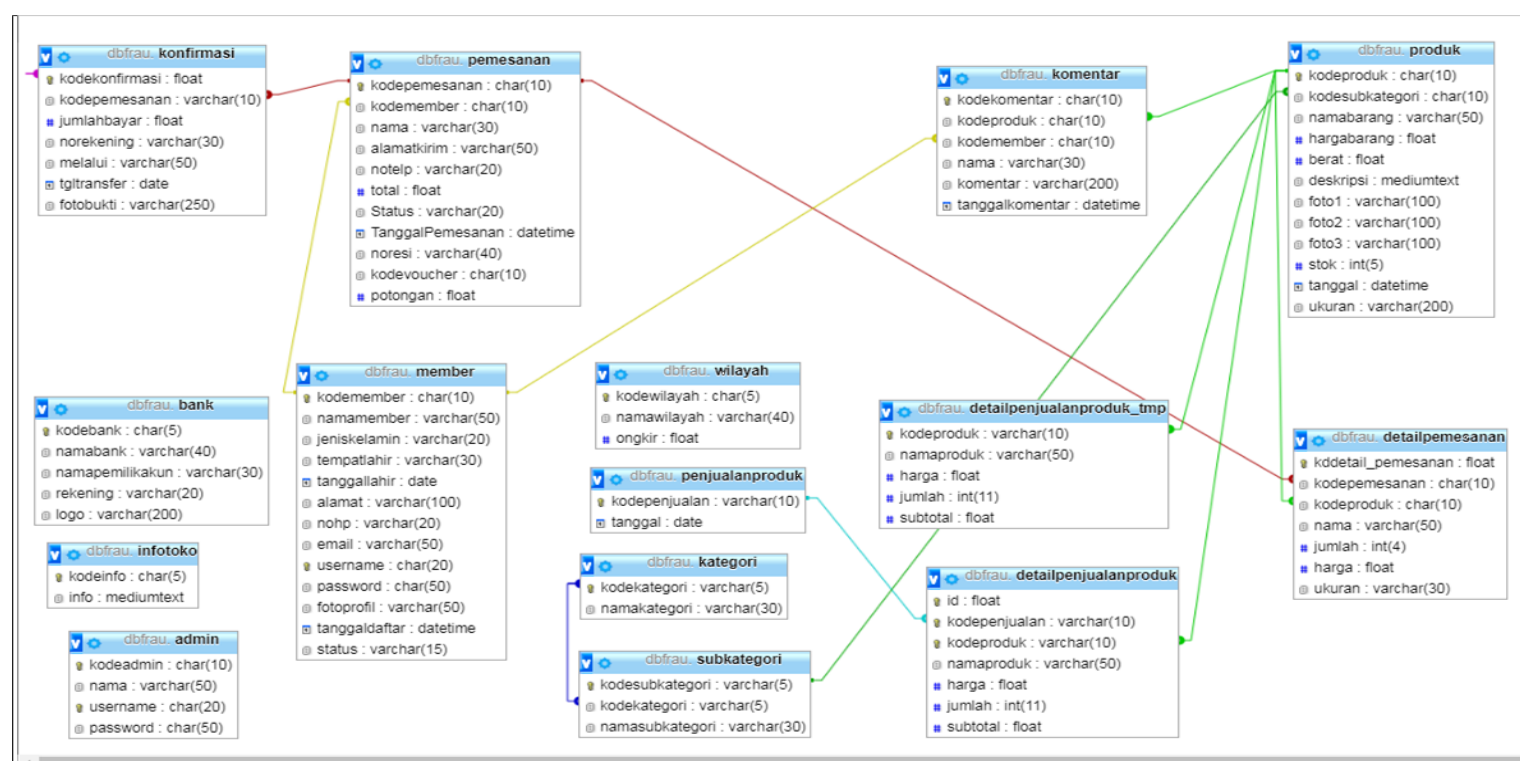

Gambar 6. Logical Record Structure (LRS)

\section{Flowchart Dokumen}

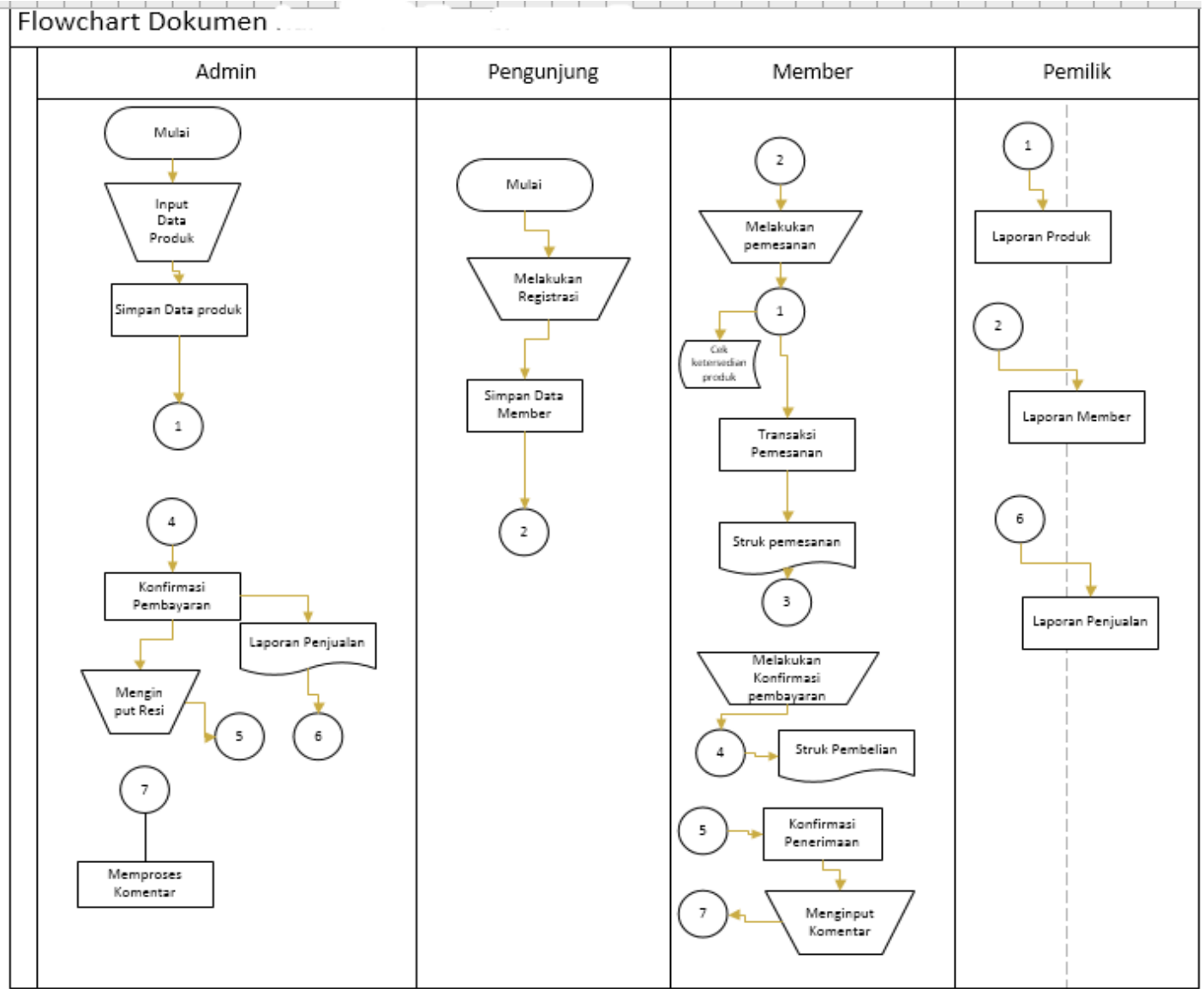

Gambar 7. Flowchart Dokumen 


\section{Rancangan Input dan Output}

\section{Rancangan Halaman Utama E-Commerce}

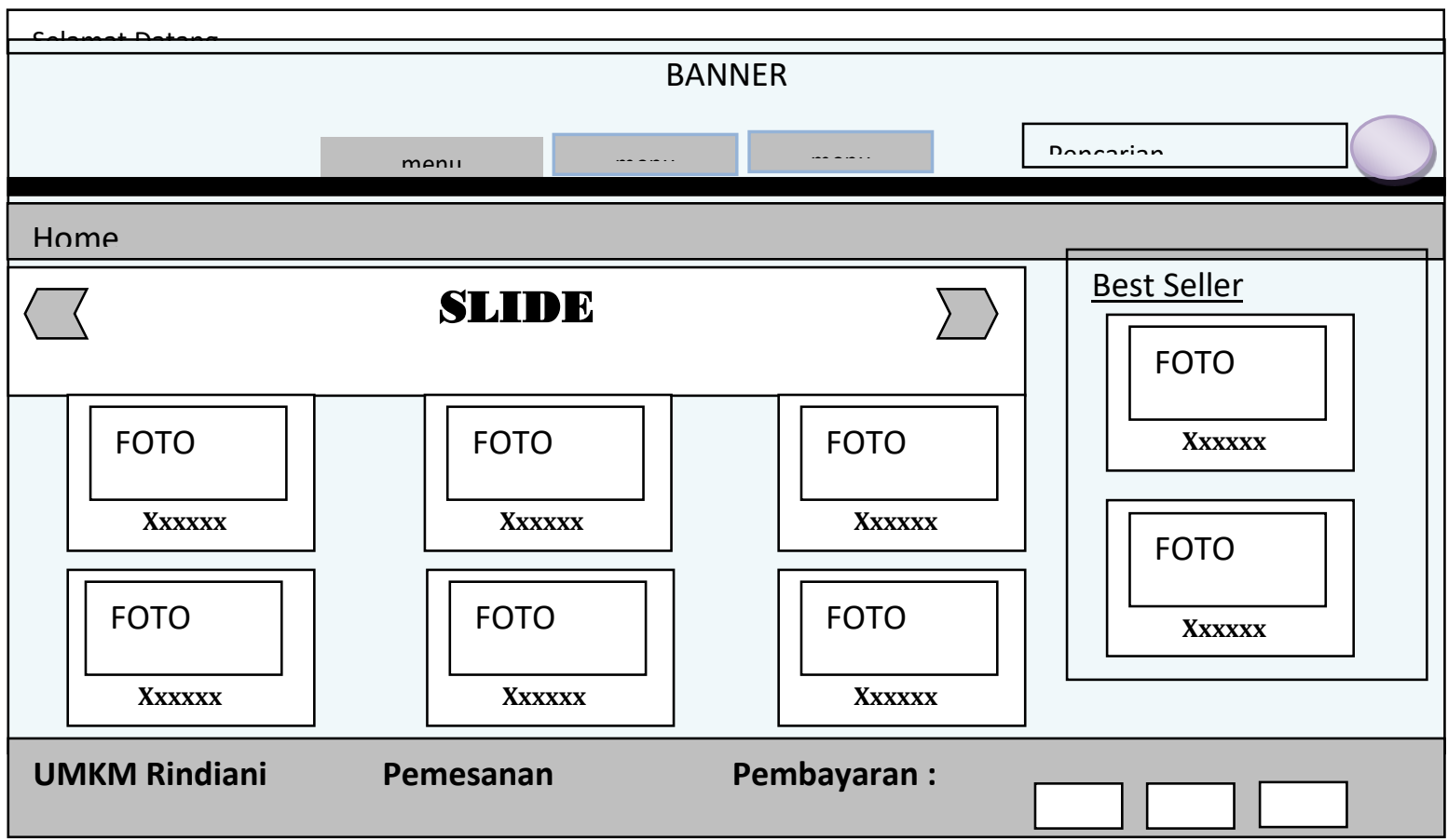

Gambar 8. Halaman Utama

\section{Rancangan Halaman Mengelola Data Produk}

Berikut adalah rancangan dari halaman mengelola data produk.

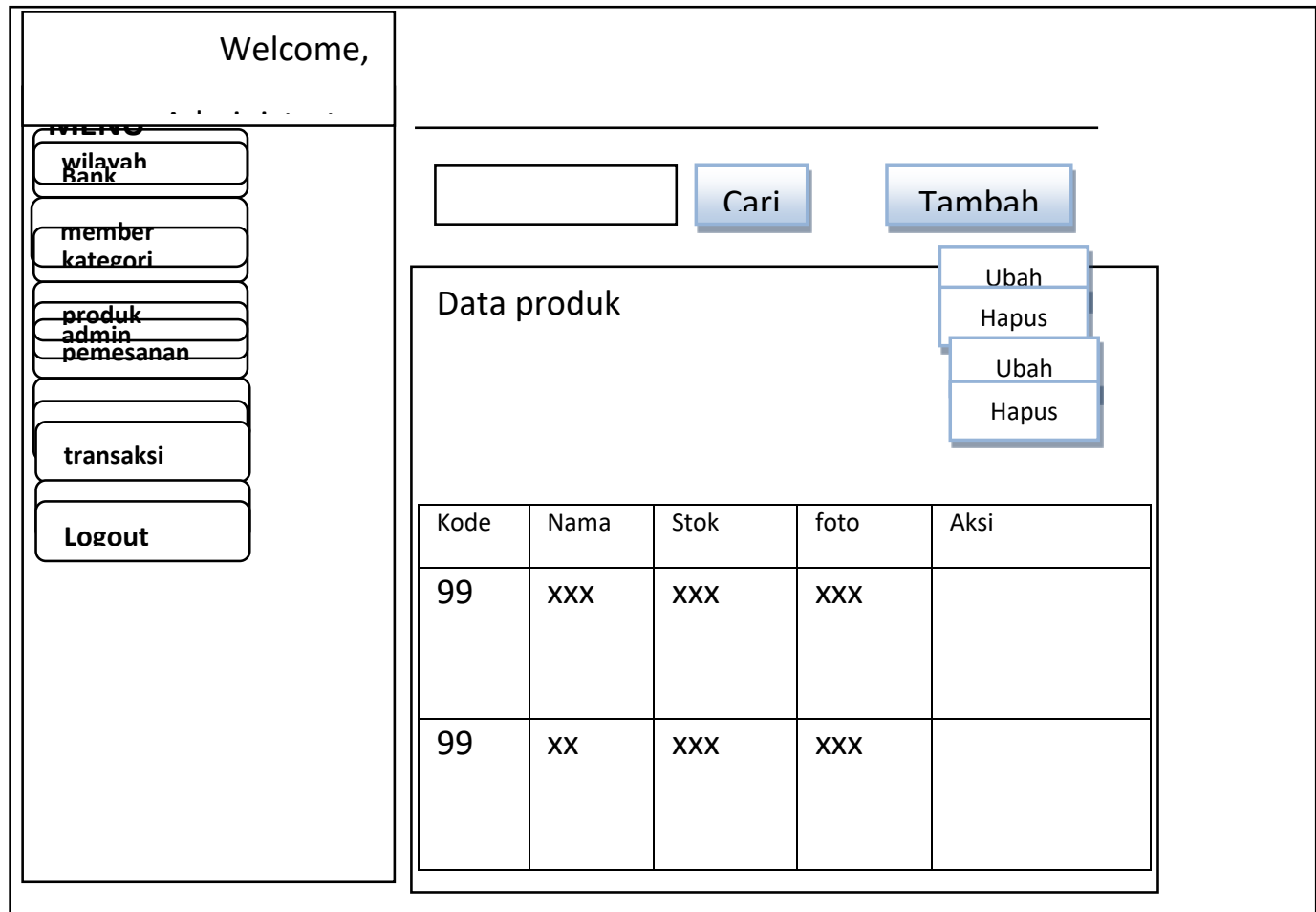

Gambar 9. Rancangan Pengelola Data Produk 


\section{Rancangan Laporan Produk}

\begin{tabular}{|c|c|c|c|c|c|}
\hline \multicolumn{6}{|c|}{$\begin{array}{l}\text { UMKM Rindiani } \\
\text { Laporan Produk }\end{array}$} \\
\hline No & Kode & $\begin{array}{l}\text { Nama } \\
\text { Produk }\end{array}$ & Harga & Total & $\begin{array}{l}\text { Tanggal } \\
\text { transaksi }\end{array}$ \\
\hline 1 & 999 & $X x x x$ & Rp. 99 & $x x x x x$ & 99 \\
\hline 2 & 999 & $X x x x$ & Rp. 99 & $x x x x x$ & 99 \\
\hline 3 & 999 & $X x x x$ & Rp. 99 & $x x x x x$ & 99 \\
\hline 4 & 999 & $X x x x$ & Rp. 99 & $x x x x x$ & 99 \\
\hline & & & & \multicolumn{2}{|c|}{ Jambi, 99-mm-yyyy } \\
\hline
\end{tabular}

Gambar 10. Laporan Produk

\section{Pengujian Sistem}

Pengujian terhadap sistem pengolah data yang telah dibuat dilakukan untuk melihat apakah software tersebut telah berjalan sesuai dengan yang diinginkan. Hasil dari pengujian tersebut dapat dilihat pada tabel 2 .

\section{Pengujian Modul Admin}

Tabel 1. Pengujian Modul Login Admin

\begin{tabular}{|c|c|c|c|c|c|}
\hline $\begin{array}{l}\text { Modul yang } \\
\text { diuji }\end{array}$ & $\begin{array}{l}\text { Prosedur } \\
\text { pengujian }\end{array}$ & Masukan & $\begin{array}{c}\text { Keluaran } \\
\text { yang } \\
\text { diharapkan }\end{array}$ & $\begin{array}{c}\text { Hasil yang } \\
\text { didapat }\end{array}$ & Kesimpulan \\
\hline $\begin{array}{l}\text { Login Admin } \\
\text { (berhasil) }\end{array}$ & $\begin{array}{l}\text { - Masukkan } \\
\text { username } \\
\text { dan } \\
\text { password } \\
\text { admin } \\
\text { secara } \\
\text { benar }\end{array}$ & $\begin{array}{l}\text { Username } \\
\text { dan } \\
\text { password } \\
\text { yang } \\
\text { sesuai } \\
\text { dengan } \\
\text { database }\end{array}$ & $\begin{array}{l}\text { Admin } \\
\text { berhasil login } \\
\text { dan tampil } \\
\text { halaman } \\
\text { utama }\end{array}$ & $\begin{array}{l}\text { Admin } \\
\text { berhasil } \\
\text { login dan } \\
\text { tampil } \\
\text { halaman } \\
\text { utama }\end{array}$ & Baik \\
\hline
\end{tabular}




\section{Pengujian Modul Mengelola Data Pemesanan}

Tabel 2. Pengujian Modul Mengelola Data Pemesanan

\begin{tabular}{|c|c|c|c|c|c|}
\hline $\begin{array}{c}\text { Modul } \\
\text { yang diuji }\end{array}$ & $\begin{array}{l}\text { Prosedur } \\
\text { pengujian }\end{array}$ & Masukan & $\begin{array}{c}\text { Keluaran } \\
\text { yang } \\
\text { diharapkan }\end{array}$ & $\begin{array}{c}\text { Hasil yang } \\
\text { didapat }\end{array}$ & Kesimpulan \\
\hline $\begin{array}{l}\text { Lihat } \\
\text { Pemesanan } \\
\text { (berhasil) }\end{array}$ & $\begin{array}{l}\text { - Klik Menu } \\
\text { pemesanan } \\
\text { - Pilih data } \\
\text { pemesanan } \\
\text { klik lihat } \\
\text { - Ubah data } \\
\text { - Klik ubah }\end{array}$ & $\begin{array}{l}\text { - No resi dan } \\
\text { status } \\
\text { pengiriman }\end{array}$ & $\begin{array}{l}\text { Data berhasil } \\
\text { diubah dan } \\
\text { Tampilkan } \\
\text { pesan "Data } \\
\text { berhasil } \\
\text { diubah" }\end{array}$ & $\begin{array}{l}\text { Data } \\
\text { berhasil } \\
\text { diubah dan } \\
\text { Tampilkan } \\
\text { pesan "Data } \\
\text { berhasil } \\
\text { diubah" }\end{array}$ & Baik \\
\hline $\begin{array}{l}\text { Lihat } \\
\text { pemesanan } \\
\text { (gagal) }\end{array}$ & $\begin{array}{c}\text { - Klik Menu } \\
\text { pemesanan } \\
\text { - Pilih data } \\
\text { pemesanan } \\
\text { klik lihat } \\
\text { - Ubah data } \\
\text { - Klik ubah }\end{array}$ & $\begin{array}{l}\text { - No resi dan } \\
\text { status } \\
\text { pengiriman } \\
\text { yang tidak } \\
\text { sesuai }\end{array}$ & $\begin{array}{l}\text { Data gagal } \\
\text { diubah dan } \\
\text { Tampilkan } \\
\text { pesan "Data } \\
\text { gagal } \\
\text { diubah" }\end{array}$ & $\begin{array}{l}\text { Data gagal } \\
\text { diubah dan } \\
\text { Tampilkan } \\
\text { pesan "Data } \\
\text { gagal } \\
\text { diubah" }\end{array}$ & Baik \\
\hline
\end{tabular}

\section{Pengujian Modul Transaksi}

Tabel 3. Pengujian Modul Transaksi

\begin{tabular}{|c|c|c|c|c|c|}
\hline $\begin{array}{l}\text { Modul } \\
\text { yang } \\
\text { diuji }\end{array}$ & $\begin{array}{l}\text { Prosedur } \\
\text { pengujian }\end{array}$ & Masukan & $\begin{array}{c}\text { Keluaran } \\
\text { yang } \\
\text { diharapkan }\end{array}$ & $\begin{array}{c}\text { Hasil yang } \\
\text { didapat }\end{array}$ & Kesimpulan \\
\hline $\begin{array}{l}\text { Proses } \\
\text { Transaksi } \\
\text { (berhasil) }\end{array}$ & $\begin{array}{l}\text { - Klik Menu } \\
\text { Transaksi } \\
\text { - Ininput } \\
\text { barang } \\
\text { - Jumlah } \\
\text { barang } \\
\text { - Jumlah bayar } \\
\text { - Klik Proses }\end{array}$ & $\begin{array}{l}\text { Kode } \\
\text { barang, } \\
\text { nama } \\
\text { barang, } \\
\text { harga } \\
\text { barang, } \\
\text { jumlah beli, } \\
\text { jumlah } \\
\text { bayar. }\end{array}$ & $\begin{array}{l}\text { Data berhasil } \\
\text { di simpan dan } \\
\text { transaksi } \\
\text { berhasil } \\
\text { diproses }\end{array}$ & $\begin{array}{l}\text { Data berhasil } \\
\text { di simpan dan } \\
\text { transaksi } \\
\text { berhasil } \\
\text { diproses }\end{array}$ & Baik \\
\hline $\begin{array}{l}\text { Proses } \\
\text { Transaksi } \\
\text { (gagal) }\end{array}$ & $\begin{array}{l}\text { - Klik Menu } \\
\text { Transaksi } \\
\text { - Klik Proses }\end{array}$ & - & $\begin{array}{l}\text { Data gagal di } \\
\text { proses }\end{array}$ & $\begin{array}{l}\text { Data gagal di } \\
\text { proses }\end{array}$ & Baik \\
\hline
\end{tabular}




\section{KESIMPULAN DAN SARAN}

\section{Kesimpulan}

Kesimpulan sementara dari beberapa kegiatan ini adalah adanya keinginan yang begitu besar dari para stakeholder yang ada di UMKM Rindiani. Untuk keberhasilan rancang bangun sistem inforamsi E-Commerce yang akan dilakukan dalam penelitian ini, dengan tujuan dalam rangka menyiapkan serta meningkatkan Pemasatran produk serta diharapkan dengan adanya sistem E-Commerce ini mampu meningkatkan Penjualan produk yang ada di UMKM Rindiani.

\section{Saran}

Perlu adanya peranan stakeholder khususnya Staf, pemilik dan pembeli yang ada di UMKM Rindiani yang terkait dengan pembuatan dan pengembangan sistem E-Commerce pada penelitian ini sehingga kedepannya proses rancang bangun aplikasi ini dapat berjalan sesuai dengan apa yang dinginkan oleh pihak UMKM Rindiani.

\section{DAFTAR PUSTAKA}

Hartono, Jogiyanto. (2005). Sistem Teknologi Informasi. Yogyakarta: Andi Yogyakarta.

Henderi. 2007. UML: Konsep dan Penerapannya Menggunakan Visual Paradigm. Mei, 20, 2016. http://www.blogster.com/henderi/uml-konsep-dan-penerapannya-menggunakanvisual-paradigm-171108195848.

Kristanto, Andri. 2004. Rekayasa perangkat Lunak(Konsep Dasar). Gaya Media. Yogyakarta

Purnama, Ridho, 2010"Analisa dan Perancangan Sistem E-Commerce dengan Mengunakan UML(Studi Kasus : Rumah Mode Namira)", Pekanbaru, Fak. Sains dan Teknologi, Universitas Islam Negeri Sultan Syarif. Riau.

Rudi,. Wahyudiarti, Retno. Megaputri, Victorani. Wihardani, Ratih., 2008,"Analisis dan Perancangan E-Commerce (Studi Kasus: Roemah Soetera Batik dan Bordir" Yogyakarta, Seminar Nasional Informatika, UPN (Peteran).

Rinaldi, Radhita. 2012,"Analisis dan Perancangan Sistem E-Commerce Pada Buku Jendela Klaten", Yogyakarta, Amikom.

Shia Harpiyan, Marcus Teddy. 2013. "Pembuatan Aplikasi Pendukung Sistim Akademik Terpadu di Universitas Kristen Maranatha dengan mengunakan Mono For Android", Jurnal Sistim Informasi Vol.8 No. 2, Bandung.

Wikipedia, 2017. "SitusWeb", diaksestgl. 21 Februari 2017,https://id.wikipedia.org/wiki/ Situs_web 